\title{
Indo-Afghan Relations after September 11: Implications for Pakistan
}

\author{
Rahil Majeed Lone* Naseer Ahmed Kalis** \\ *Rahil Majeed Lone is a PhD Scholar in the Department of Political Science, Barkatulla University, Bhopal, \\ $(M P)$. \\ **Naseer Ahmed Kalis is Junior Research Fellow in the Department of Strategic and Regional Studies, \\ University of Jammu, 180006, ( $\mathrm{J} \&$ K.)
}

\begin{abstract}
This paper will analyse the Indian engagement in Afghanistan as soft power since September 11, and its impact on Pakistan. This approach has threatened Pakistan as Pakistan does not want India's stable and peaceful relations with Afghanistan. Pakistan's wants to destabilize Indo-Afghan relations due to her covert relations with afghan's non-state actors. Since 2001, Afghanistan's Foreign Policy towards New Delhi is quite receptive. India has growing stakes in peace and stability in Afghanistan. India's activities in Afghanistan had a geo-strategic flavour though, which not only confine to Afghanistan but travel deep into Central Asia. It is now widely accepted that India's Afghan policy seeks access to energy resources of the region. If India-PakistanAfghanistan cooperates by recognizing one another as opportunities not as threat, the level of trust deficit will minimize and a new era of peace will like to see.
\end{abstract}

Key Words: Soft Power, Geopolitical, Strategic Depth, Asymmetric Strategies.

\section{Introduction}

Some of our toughest challenges lie in our immediate neighbourhood. The fact is that we cannot realise our growth ambitions unless we ensure peace and stability in South Asia. ${ }^{I}$

It is the strategy of every nation in International Relation to scatter their influence in neighbouring areas through diplomatic, ideological and Political and military means. From South Asian point of view, New Delhi has long been an exclusive player of influence and has sought to prevent the intervention of external powers in the affairs of the region. India has some key features which witnessed India's rise. It is the preeminent country in South Asia in terms of size, population, economy and military power. It accounts for three quarters of the population as well as the geographical area of South Asia, 80 per cent of the total GDP of the region, and spends five times more than the rest of the countries put together on its defence. ${ }^{2}$ India is also the member of various organizations of Asia and outside. India has tried to maintain good and friendly relations with immediate and extended neighbours. The Indo-Afghan relationship is not a simple bilateral engagement rather beyond. India's Afghan policy is driven by, and is dependent on, many extraneous factors like India's troubled relationship with Pakistan, its search for a land transit to Central Asia through Iran and Afghanistan and its concerns regarding use of Afghan territory by Pakistan to the detriment of Indian interests. Given the geographical constraints, India has relied on Iran for land access to Afghanistan. India has also tried to address Pakistani apprehensions regarding its engagement in Afghanistan. Its decision to resume bilateral dialogue in spite of domestic pressures against any such initiative post-Mumbai and the inclusion of Balochistan in the joint statement issued at Sharm-al-Sheikh in 2009 are part of New Delhi's policy to build confidence with Islamabad. Simultaneously, India has gained enormous political capital through its economic engagement with other countries of the region. This is likely to help it to sustain its presence in Afghanistan after 2014, when the Taliban may be a part of the government in Kabul or will wither away or came in power once again.

Afghanistan has experienced a relentless welter of swift and jarring changes in its recent history. Since the 1970s, following a fifty-year period of relatively peaceful and gradual development, Afghanistan was whipsawed through Cold War great-power competition, accompanied by a Soviet invasion, Communism, and jihadism; fratricidal civil war perpetrated by ethnic militias acting as regional proxies; the rise of Taliban and Bin Laden; and pacification and democratization under U.S.-led military intervention. Over the past thirty years, perhaps half of the population has been displaced, with one-third leaving the country altogether. More than a million Afghans were killed, and millions more were wounded, traumatized, or died prematurely due to the lack of sufficient food, clean water, or basic medical care. The educated and skilled left the country, arms flooded in, and the scourge of crime, corruption, drugs, and a culture of impunity has overwhelmed the economy and traditional structures of governance and peacemaking. ${ }^{3}$ The history of the Afghans is a web of intrigue, repression, ethnic cleansing, revolt, deception and foreign interventions; they value their freedom and would always like to be free from external rule. The present pro-US Afghan regime is unable to determine the future of 
Afghanistan as it has failed to win the confidence of the people. The Pakhtuns and non-Pakhtuns in the government have divergent opinions on countless issues, including power sharing. The government is also under challenge from independent warlords, poppy producers, smugglers and the ousted Taliban guerrillas who the government says are jumping into the fray with external support (allegedly from Pakistan). All potential forces of disruption ethnic, sectarian and tribal are casting ominous shadows which could lead to disintegration of the country. ${ }^{4}$

In such a situation, India engaged herself in Afghanistan for reconstruction as a soft power. The United States, Pakistan, France, and other Coalition countries as hard power, mere to retaliate form Taliban and Al Qaida. India has taken some steps such as signing the Gas Sales and Purchase Agreement (GSPA) relating to the Turkmenistan, Afghanistan, Pakistan and India (TAPI) pipeline, while also reduces its dependency on oil imports from Iran. Yet it has made it unequivocally clear to the US that snapping ties with Iran is not an option due to India's economic linkages with Iran and its relevance for New Delhi's presence in Afghanistan.

India has adopted soft power approach towards Afghanistan, to revive its historical, traditional, sociocultural and civilizational linkages with the country. India's role is seen as crucial for the long-term stability of Afghanistan, and India realizes that a stable, prosperous and democratic Afghanistan is also in its strategic interests. India's approach toward Afghanistan has largely been a function of the desire to prevent Pakistan from dominating that country, Islamabad views as a vital counterweight to India's preponderance in South Asia. The two countries have been stuck in a classic security dilemma in so far as their Afghan policies are concerned, in that any measure by either side to increase its security is liable to trigger a reaction thus causing deterioration in the overall regional balance. There is trust deficit between India and Pakistan that is why there relations are not stable. India's relations with Afghanistan have improved steadily since the fall of the Taliban for a number of reasons. Firstly, India's active role in the construction process in Afghanistan to create a vast platform to access with Central Asian region, Secondly, to minimise the influence of Pakistan in the region, Thirdly, Pakistan is perpetually creating troubles in Kashmir through its home grown non-state actors that have covert relations with Afghan non-state actors (Al Qaida and Taliban). Thus India does not want these non state actors to be used against India by Pakistan, Fourthly, India's support for the Northern Alliance against the Pakistan-backed Taliban in the 1990s strengthened its position in Kabul after 2001 as many Alliance members have come to hold key government posts, Fifthly, to support various ethnic groups that supports president Hamid Karzai, a Pushtun who studied from India. The international community has been ambivalent about India's profile in Afghanistan. While the Afghan government and its international partners welcome India's constructive role, many also worry about the negative externalities associated with India's footprint in the country, particularly with respect to Pakistan. Pakistan has long feared Indian encirclement and complains sharply about India's expanding presence in Afghanistan. ${ }^{5}$ The long term interest of India in Eurasia can be fulfilled when there is convergence between India-Pakistan-Afghanistan.

\section{Indo-Afghan Cooperation}

After the event of 9/11, Afghanistan again has to face the situation of turmoil and chaos due to attack of NATO forces headed by U.S. It is not NATO forces alone but India, China, Russia, Pakistan, and Iran are also key actors in Afghanistan with differ interests. They are playing their role to meet their strategic and political interests in the region. India is a stable country of Asia that has the potential to play a dominant role to play. As far as India is concerned, it is not member of NATO but it is very active for reconstruction and economic development of Afghanistan. India does not take part in military activities in Afghanistan from coalition sides due to various reasons.

Firstly, India does not provide land, air or sea routes to the coalition forces like other regional countries because India did not want to sacrifice the core value of national unity. Secondly, the war on terrorism was against pre known militant organisations in Afghanistan like Taliban and Al Qaida. In other words, it was against Muslim radical and extremist organisations. If India provides any land, air or sea base, it may hit the sentiments of Muslims of India. Thirdly, Non- involvement in front of war against Afghan has minimised the anti Indian sentiments among the Afghan. India's involvement in Afghanistan was on convergence fronts like trade, process of re-build Afghanistan, energy, roads, railways etc.

Lastly, India wants to secure and strengthen the $1735 \mathrm{~km}$ long- Turkmenistan-Afghanistan-PakistanIndia (TAPI) gas pipeline to fulfil her energy requirements. On the other, Pakistan's domestic gas pipelines are till date being targeted by Tahreek-e-Taliban-Pakistan (TTP). ${ }^{6}$

Indian assistance has focused on building human capital and physical infrastructure, improving security, and helping the agricultural and other important sectors of the country's economy. The Indian government is building roads, providing medical facilities, and helping with educational programs in an effort to develop and enhance long-term Afghan capabilities. ${ }^{7}$ India adopted peaceful means and method to access with Afghanistan because India does not wants to scrap its ties with Afghanistan at the wake of global war on terror. India's engagement in Afghanistan is motivated by national security, energy security and geo-strategic 
compulsions. Indian Prime minister, Atal Bihari Vajpayee assured Hamid Karzai that "Indian people are committed to stand by our Afghan friends in this hour of need. The task of rebuilding and reconstructing Afghanistan is enormous. Our unflinching and unconditional cooperation is available to the Afghan nation, as it pursues the return of prosperity and restoration of peace and stability in Afghanistan. We have made some contributions towards humanitarian assistance, reconstruction and rehabilitation. We are prepared to do much more". ${ }^{8}$

Currently India is one of the biggest donors of Afghanistan, both states have signed many treaties and agreements of cooperation, and this shows the long-term interests of India in Afghanistan. India wants to marginalize Pakistan's influence in the region by increasing its influence in Afghanistan. By doing so, it can get secure access to Central Asian Republic's natural resources as well. India's interests in Afghanistan have centred on supporting the nascent democratic regime, thereby denying space for the return of the Taliban. As a major regional power, with ambitions of extending its influence beyond its immediate neighbourhood, India has worked towards reviving the role of Afghanistan as a land bridge, thereby connecting South Asia with Central Asia to tap the energy resources of the region. With the prospects of linking stability with greater economic integration, India has actively promoted greater trade and economic integration of Afghanistan with South Asia through the regional economic mechanism of the South Asian Association of Regional Cooperation (SAARC). India also piloted the move to make Afghanistan a member of the South Asian Association of Regional Cooperation (SAARC), with the hope that with the entry of Afghanistan into the SAARC, it will become a permanent and easy bridge between South Asia and West and Central Asia that leading to the greater economic development of Afghanistan and the region as a whole. Since 2001 India has been involved in many developmental projects, one of the major projects is the 280 kilometres strategic road in Afghanistan that link it to Iran border, India has provided $\$ 80$ million for this project. Reconstruction of the Salma Dam power project is also competed with assistance of India. During the visit of Hamid Karzia to Delhi, India and Afghanistan signed the preferential trade agreement, according to which 38 items that Afghanistan exports to India have been given $100 \%$ tariff concessions. ${ }^{9}$ India is the fifth largest bilateral donor country (behind US, Japan, UK and Germany ) providing millions of aid in diverse areas, including infrastructure, communications, education, healthcare, social welfare, training of officials, including diplomats and policemen, economic development and institution-building. These sectors have been identified by the Afghan Government as priority areas of development. ${ }^{10}$ India is involved in long-term projects like electricity transmission; hydro-electric power generation, road construction, parliament building construction, industry and agriculture to kick start Afghanistan's energy and infrastructure requirements. India's Power Grid Corporation is constructing $220 \mathrm{kV}$ Double Circuit Transmission Line from Pul-e-Khumri in the Banghlan province to Kabul and a 220/110/20 kV Substation at Kabul at an estimated cost of US $\$ 111$ million (Rs 478.72 crore) involving the construction of 600 transmission towers. The project on completion in February 2009 will supply electricity to Kabul from the Termez power project in Uzbekistan. India has also supplied equipment for the $110 \mathrm{kV}$ transmission line (130 $\mathrm{Km}$ long) and $20 \mathrm{kV}$ transmission line (150 Km long) along with $20 / 0.4 \mathrm{kV}$ substation and $110 \mathrm{kV}$ and $20 \mathrm{kV}$ transmission line material, in Faryab province of northern Afghanistan at a cost of around Rs 39.2 crore. India also helped in constructing Afghanistan's new Parliament building at an estimated cost of US \$ 75 million. ${ }^{11}$ Indo-Afghan joint projects include hydroelectric projects and building roads: electricity transfer from Central Asia to Afghanistan, the Zaranj and Dellaram road that connects Afghanistan to Iran, and the Chahbahar sea port in Iran to be used for exports/imports between India-Afghanistan-Central Asia as part of a 2003 trade agreement are important strategic programs. ${ }^{12}$ India has also engaged in training of Afghan civilian and military personnel as well as providing Afghan students with scholarships to study in India. The Indian Council for Cultural Relations (ICCR) has offered as many as five hundred scholarships a year for Afghans. India is keen to have a much larger role in training Afghan National Security Forces. India also brought Gas pipelines via Afghanistan named Turkmenistan-Afghanistan-Pakistan-India (TAPI) gas pipeline. This gas pipeline is passing through conflict prone areas like Afghanistan and Pakistan, thus the biggest challenge for New Delhi is its security.

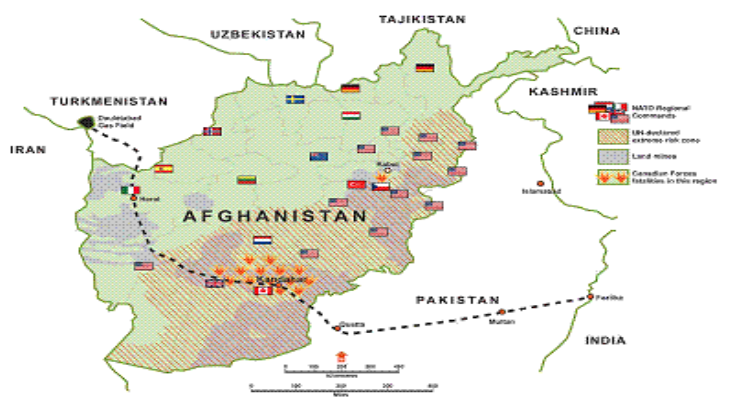

Map: Route of TAPI gas pipeline. 
India also realises that stability can result in Afghanistan only if all the major actors and countries have a stake in its stability, growth and prosperity. India has, thus, been championing efforts to attract regional and trans-regional investment into Afghanistan that provides a viable alternative to the dominant narrative of extremism and offers job opportunities to its population, by pioneering events like the Delhi Investment Summit on Afghanistan in June 2012. ${ }^{13}$ In 2011, India and Afghanistan has signed strategic cooperation agreement in to boost development and security cooperation between the two nations. Indian prime minister, Manmohan Singh said, he had frank discussions regarding terrorism threats during his meeting with Afghan president Hamid Karzai. Hamid Karzai acknowledged India's efforts to bring peace and stability in the region. India is considered as a major power in the region and the country has played an important role in Afghanistan reconstruction after the fall of the Taliban regime in 2001. India has committed \$2 billion funds in Afghanistan reconstruction and development projects, and the construction of a new parliament building is one of the most important contributions of India in Afghanistan reconstruction. President Karzai's visit to India takes place in such a situation where tensions between Afghanistan and neighbouring Pakistan have escalated in regards to fight against terrorism. On the other hand, India is concerned regarding the expansion of violence in the region in such a time where the International coalition forces are planning to withdraw from Afghanistan. ${ }^{14}$ This Strategic Partnership Agreement (SPA) between the two sides, provides for assistance to help rebuild Afghanistan's infrastructure and institutions, education and technical assistance to re-build indigenous Afghan capacity in different areas, encouraging investment in Afghanistan's natural resources, providing duty free access to the Indian market for Afghanistan's export products, support for an Afghan-led, Afghan-owned, broadbased and inclusive process of peace. From the Afghan side, high level visits to India included President Hamid Karzai's state visit in November, 2012, had intensive discussions with political and business leaders and oversaw the signing of four Memorandum of Undertakings (MoUs) with India. No doubt Afghanistan has geo strategic importance for India but Pakistan is also an important factor that acts as a bridge between the two. Sajjad Ashraf, a former Pakistan ambassador to Singapore talks about the economic and strategic and geopolitical importance of Afghanistan for India and Pakistan and suggests that the countries involved want to develop Afghanistan s a hub linking South and Central Asia since it sits in both regions. Pakistan which by its geography as landlocked Afghanistan's neighbour with the longest border has a key role to play. On Indoafghan policy he said that it too will benefit Pakistan and said, "If the three countries can reach an understanding and let India develop Afghan capacity leading to regional economic integration, Pakistan too becomes a winner. In the age of globalisation, following any other course will result in Pakistan lagging behind" ${ }^{15}$ For India, peace in Afghanistan is important to be able to access the vast economic potential of the Central Asian states. It shares Afghanistan's concerns about the security of the nation after the western withdrawal from a combat role in 2014. He further added that India is concerned, which everyone should be, at the return of a medieval Taliban like regime in Kabul that could become the staging ground for cross border extremism into India. It makes little sense for India to keep the borders with Pakistan tense, least of all turning up the heat on its western flank with Afghanistan, Ashraf said. India doesn't have a contiguous border with Afghanistan and the last thing it needs is a costly entanglement there. Besides, it is obvious to everyone, including the strategic community in India, that there cannot be lasting peace in Afghanistan without the support of Pakistan. ${ }^{16}$ US also declared India as an important player in Afghanistan, US Secretary of State John Kerry acknowledged that because of the relationship between New Delhi and Islamabad it is "complicated circle" between the war-torn nation, Pakistan and India and added that "India can play a huge role."17

In the post-2014 scenario, the role of regional countries will increase. India, China, Russia and Pakistan will gear up to assume a bigger role in Afghanistan. China will try through its Chinghai Cooperation Organization (SCO), Russia will try to dominate through its Collective Security Treaty Organisation (CSTO). The nature of domestic instability in Afghanistan will determine whether post-withdrawal the Afghan forces will be able to meet the challenges effectively. It is still uncertain as to who will succeed President Krazai. Moreover, the reconciliation efforts do not seem to be succeeding. There is no regional consensus on how to approach the post-withdrawal situation. Pakistan is looking for strategic depth; Iran wants to see the back of American forces from Afghan soil; China eyes Afghan resources without any definite commitment to invest in Afghan security and stability; Russia is ready to engage as a service provider if the funds can be arranged elsewhere. All in all, there is not enough international support for keeping the 'new Afghanistan' afloat. Therefore, the obvious alternative scenario is staring us in the face-incessant turmoil, political instability and possible civil war leading to chaos and disorder. Against this backdrop, it is necessary to take stock of the evolving situation in Afghanistan and suggest policy options for India in the changing context. ${ }^{18}$ Having invested US\$1.3 billion and gained much goodwill, India has no choice but to stay on in Afghanistan. India must continue to operate its consulates in Jalalabad, Kandahar, Herat and Mazar-e-Sharif even after the withdrawal of the coalition forces. The presence is required as a lookout post in the region. The Iran route can open up fully in future. It is the gateway to Central Asia. 


\section{Pakistan's Asymmetric Strategies}

Pakistan and Afghanistan are Muslim neighbouring countries, and share more than 2,500 kilometres of border, called Durand Line, which was demarcated in 1893 following an agreement between the British Empire and the Afghan king. The Durand Line divides ethnic Pashtun tribes in the Pak-Afghan border areas. Ethnically, Pashtuns constitute the majority of the population of Afghanistan and also have considerable population in Pakistan. They are Pashtu speaking people of south-eastern Afghanistan and north western Pakistan. ${ }^{19}$ Thus, the state with the closest ties and strongest links to Afghanistan is Pakistan. It is a proactive rather than reactive player. Pakistan's military rulers saw the war in Afghanistan as an opportunity to reverse Pakistan's antagonistic relations with Afghanistan over Pashtunistan, providing it with "strategic depth" in its confrontation with India. Pakistan is sitting between India and Afghanistan and shares border with Afghanistan and India as well and would also be impelled by geopolitical considerations with regard to India. Pakistan was the first country formed on religious lines but the dream of Mohammad Ali Jinnah, the Founder of Pakistan, is not fruitful because today Pakistan is living in gun culture. Everywhere there are conflict, violence, and insecurity. Muslims are killing their fellows; Is Pakistan was created for this?

Pakistan's approach after September 11 was marked by various ups and down. Pakistan government decided to support US as US gave an ultimatum that you are either with us or against us, majority of people were against this move. It was not an easy road for Pakistan to negotiate over the course of the two months after September 11. Pakistan sees its main security task as obtaining parity with India, a country almost eight times larger, which has resulted in the ruination of Pakistan's economy due to excessive military spending, the use of "asymmetric strategies" such as support for insurgencies and extremist groups and the quest for "strategic depth" - links and alliances with parts of the Muslim world to the west. These asymmetric strategies have devastated the internal stability of Pakistan because the gun culture which Pakistan supported during 1980's has become a regular feature today. The quest for "strategic depth" has defined Pakistan's policy toward Afghanistan and then Central Asia for decades. After the initial decision to join the anti-Taliban (and anti-AI Qaeda) international coalition, the passage was made hesitantly, if not reluctantly. General Musharraf had to face continuous vigorous public demonstrations, notably in Peshawar, Quetta and Karachi, protesting the decision to abandon the Taliban and join the U.S.-led international coalition. Pakistan, repeatedly hailed by Washington as a "crucial" partner and ally, naturally expected rewards, By late October, the U.S. had given Pakistan $\$ 600$ million in cash and was preparing an aid package "likely to total several billion dollars". ${ }^{20}$ India's approach in Afghanistan was to participate in the economic development, support the Afghan central government and attempts to prevent the Taliban back to power again. Overall, India's approach towards the new government of Afghanistan after the September 11, 2001, has been a cooperative and positive approach. Indian influence in Afghanistan has re-acquired after September, 11. India's prestige is growing in Afghanistan and this ties whit Kabul in various fields is expanding rapidly. India's peaceful move in Afghanistan after 9/11 as a soft power was jolting factor for Pakistan because Pakistan does not wants India's influence in Afghanistan and tried to derail India's policy in Afghanistan through the attacks on Indian working in Afghanistan's reconstruction process. Pakistan's policy in Afghanistan on the other derives from its quest for security from India and its intelligence services use Afghan territory to train fighters for Kashmir. Pakistan has a great stake in a stable and peaceful Afghanistan but faces problems in convincing post-Taliban afghan leaders of its sincerity. Pakistan believes Afghanistan's territory is being used by India, in connivance with afghan leaders and intelligence agencies, to interfere in the Baluchistan Province of Pakistan and in other trouble spots. Afghanistan has not ceased accusing Pakistan of intervention and using the afghan Taliban as an instrument of Pakistani regional policy. ${ }^{21}$ Pakistan does not want external players in Afghanistan and points that it is a destabilising factor for Pakistan. Acc. to Pakistan's Foreign Office spokesman, "Pakistan did not demand that Afghanistan should 'cut all ties to India' and has no objection ... We have only stressed that those external forces which are using the soil of Afghanistan to destabilise Pakistan should be discouraged. ${ }^{22}$

\section{India-Pakistan-Afghanistan: Future Prospects of Peace}

There are strong evidences in the scholarly literature that India, Pakistan and Afghanistan have suffered from terrorism, conflict and violence that have their roots in their own countries as well as outside. The extremist organisations of these countries have transnational character. Peace among these countries is on anvil and beaten by the non state actors from the last six decades. India and Pakistan are facing trust deficit, hostility and divergence relations from the day one of their independence. Their long standing unsolved territorial issues have created the atmosphere of chaos and hostility. India and Pakistan have no doubt their own national interest in Afghanistan and beyond. It is not easy for India and Pakistan to cooperate in Afghanistan due to distrust and varying geopolitical, economic and security issues. The security dynamics of Afghanistan, Pakistan and India remain intractably interlinked. Given their shared histories, shared borders and shared ethnicities, any political and strategic development in anyone of these countries finds resonance in the other two. Since Soviet intervention in Afghanistan in 1979 there is political downfall in Afghanistan. The five years of Taliban rule, 
aliens rule in Afghanistan has created chaos and real victims were the people. From the last 12 years, Afghanistan has become the arena of external forces. Many countries supported while other criticised the interference in Afghan territory. India's support to Hamid Karzai regime and Pakistan's covert nexus with Taliban and Al Qaida can not necessarily bring peace rather without the cooperation of Civil Society. After the withdrawal of alien forces from Afghan territory in 2014, there is a ray of hope for the three nations from to cooperate, because Afghanistan needs some sort of India's and Pakistan's cooperation. New Delhi also needs Pakistan's and Afghanistan's support to access with gas pipeline borrowed from Turkmenistan as well as to Central Asia. Thus New Delhi, Islamabad and Kabul need to create a platform for mutual trust, strategic engagement and negotiation as a means of conflict resolution for future progress and prosperity. Democracy and stabilization of Afghanistan highly depends on the level of support by the external players like India, Pakistan, and US etc. The donor agency should contribute in the development and reconstruction process for long term. Pakistan should act like India in Afghan and should shun supporting ethnic groups and non state actors. Pakistan should know that Afghanistan is both an 'opportunity' as well as 'threat' for their long term policy. If they perpetually support Afghan non state actors, they will realize Afghanistan as threat in their country as well and if they start sharing in developmental projects for Afghan construction, they will find Afghanistan as opportunity to trade with them as well as central Asia. Moreover, the stability and cooperation between these tri nations will also strengthen regional organisations like SAARC.

\section{End Notes}

[1]. Ashok K. Behuria, et al. “Does India Have a Neighbourhood Policy?”, Strategic Analysis, 36,(2), 2012, p. 230

[2]. Ibid. $\mathrm{p}, 229$

[3]. J Alexander Thier, (ed.), "The Future of Afghanistan", (Washington, DC: United State Institute of Peace, 2009), p.2

[4]. Omar Farooq Zain, "Afghanistan: From Conflict to Conflict", Pakistan Horizon, Vol. 59, (1), 2006, p.79. [Accessed on 12/04/2013]

[5]. C. Christine Fair, "India in Afghanistan and Beyond: Opportunities and Constraints", (Washington DC: The Century Foundation, 2010), p. 4.

[6]. Shaheen Showkat Dar and Naseer Ahmed Kalis, "India's Strategic Response to War on Terrorism in Afghanistan: A Strategic Analysis", International Journal of Humanities and Social Science Invention, Vol.2. (5), May 2013, p. 21.

[7]. Harish V Pant, “The Afghanistan Conflict: India's Changing Role”, Middle East Quarterly, Spring, 2011, p 32

[8]. Richard J. Kozicki, "The Changed World of South Asia: Afghanistan, Pakistan, and India after September 11", Asia Pacific Perspectives, Vol. 2(2), 2002, p. 8

[9]. Iram Khalid, "The New Great Game in Afghanistan: Role of India (A Pakistani Perspective)" South Asian Studies, Vol. 26 ( 2), 2011, p 244.

[10]. Shanthie Mariet D’Souza, “India’s Aid to Afghanistan: Challenges and Prospects” Strategic Analysis, Vol. 31, (5), 2007. p. 833.

[11]. Ibid.836.

[12]. Qandeel Siddique, "Pakistan's Future Policy Towards Afghanistan: A Look at Strategic Depth, Militant Movements and the Role of India and US" (Copenhagen: Danish Institute for International Studies(DIIS), 2011), p. 42

[13]. India-Afghanistan Relations, February, 2013, http://www.mea.gov.in/Portal/ForeignRelation/afg.pd.

[14]. Ghanizada, “Afghanistan \& India sign strategic cooperation agreement”, Khaama Press, October,4, 2011, http://www.khaama.com/afghanistan-india-sign-strategic- cooperation-agreement.

[15]. Sanjeev Miglani, "India Afghanistan Strategic Pacts: The Beginnings of Regional Integration", Reuters November,11, 2011, http://blogs.reuters.com/afghanistan/2011/11/11/india-afghan-strategic-pactthe-beginnings-of-regional-integration/

[16]. Ibid.

[17]. PTI, "Indo-pak relations might affect India's Afghan Role” The Hindustan Times, April 18, 2013, http://www.hindustantimes.com/world-news/NorthAmerica/Indo-Pak-relations-might-affect-India- s-Afghan-role/Article11046209.aspx.

[18]. Arvind Gupta, Ashok. K. Behuria et.al. , "Post-2014 Afghanistan and India's Options", Institute of Defence and Strategic Analysis. July 18, 2012. http://www.idsa.in/policybrief/Post2014AfghanistanAndIndiasOptions 180712.

[19]. Safdar Sial, "Pak-Afghan Relations: Emerging Trends and Future Prospects" Conflict and Peace Studies , Vol.4,(1). (Jan-Mar.) 2011, p.1.

[20]. Richard J. Kozicki, "The Changed World of South Asia: Afghanistan, Pakistan, and India after September 11" n.2. p.5.

[21]. Rasul Bakhsh Rais, "Afghanistan and Pakistan: Difficult neighbours" in Post -September 11" Afghanistan-Pakistan Relations: Prospects for Counter-insurgency Cooperation, National Bureau of Asian Research Analysis. Vol. 19 (5), 2008.

[22]. Anita Joshua, "Pakistan denies asking Afghanistan to snap ties with India", The Hindu, March 29, 2013. 